\title{
THE EFFECT OF SERVICE QUALITY ON CUSTOMER SATISFACTION IN DIGITAL AGE: CUSTOMER SATISFACTION BASED EXAMINATION OF DIGITAL CRM
}

\author{
Demokaan DEMIREL \\ Department of Political Science and Public Administration, \\ Faculty of Economy and Administrative Sciences, Kocaeli University, İzmit/Kocaeli, Turkey
}

Received 12 October 2019; accepted 28 June 2021; first published online 23 February 2022

\begin{abstract}
This study examines how customer-centered management systems contribute to CRM through the use of digital services. The article presents empirical evidence from an online survey of 405 people using digital services living Kocaeli province in Turkey and modelling a system of structural equations using partial least squares. 405 people have been selected by a random sampling method to ensure objectivity and scientific neutrality. Among the 405 people, 350 were found to have filled out the questionnaire completely. The study also examined the relationship between the dimensions of service quality and customer satisfaction. The results confirm that most of the dimensions of digital service quality favour the development of customer satisfaction capabilities and both the relationship the independent variables and trust, Enthusiasm, and sensitivity dimensions and customer satisfaction are positive. High customer satisfaction with digital services can lead to superior firm performance; however, companies should also gain credibility for customers and should design their products according to customer preferences.
\end{abstract}

Keywords: CRM, service quality, digital services, technological capabilities, information technology, customer relationship performance.

JEL Classification: M1, M15.

\section{Introduction}

Today, four major changes shape the business environment. The first change is the gradual strengthening of the global economy. The second change is the transformation of industrial economies into knowledge and information-based service economies. The third change is the differentiation of business structures. Businesses are now based on flat, flexible teamwork. The fourth change is the emergence of a digital firm. Digital relationships are established between customers, suppliers, and staff. Business processes are shaped through digital networks. Corporate assets are managed in a digital environment sensitively to environmental changes.

*Corresponding author. E-mail: demokaand@gmail.com

Copyright (c) 2022 The Author(s). Published by Vilnius Gediminas Technical University

This is an Open Access article distributed under the terms of the Creative Commons Attribution License (http://creativecommons. org/licenses/by/4.0/), which permits unrestricted use, distribution, and reproduction in any medium, provided the original author and source are credited. 
Information systems provide companies with the necessary communication and analytical power to manage commercial relationships and organizations on a global scale. Understanding and meeting individual customer requirements have been an important dimension for companies that want to gain a competitive advantage. Companies update their processes and applications harmoniously with the customer concept. The responsibilities of companies towards their stakeholders and customers are increasing. Information technologies structure more than $70 \%$ of the investment services sectors such as finance, insurance, and real estate. To be competitive in international markets, strong information and communication network is required (Kumar \& Reinartz, 2018, p. 4; Laudon \& Laudon, 2017, pp. 3-5).

Firms are shifting their focus from sales targets to emotional bonding with their customers. Satisfying the target audience and understanding the unique challenges facing customers is seen as an important issue. The quality of the relationship between the firm and the client depends on the level of satisfaction resulting from the relationship and the client's emotional commitment to this relationship (Pansari \& Kumar, 2017, pp. 295-298).

Integrating all customer contact points is essential for digital operations. Consistency supports customer satisfaction and strengthens the brand. Continuity and transparency in content ensure perfection in communication with the customer (Berman, 2012, p. 229). This study specifically considers how digital practices of CRM separately affect organizational service quality and how digital improvements and CRM practices interrelate to achieve a positive effect on organizational structures and customer satisfaction. The current academic literature and CRM applications do not specifically provide clear data on the process. For this reason, it is important to identify functional and organizational capabilities to manage effective and profitable CRM activities. Drawing from the literature in digital transformation, ICT, and customer management relations, and the first contribution of this study is the conceptualization of digital CRM capability in organizations. The second important contribution is to test how an organization's CRM ability affects organizational service quality and relationships with customers. The main problem of the study is to analyze the effects of the dimensions of digital service quality on customer satisfaction according to the structural equation model (SEM).

The study is important as it examines whether there is a meaningful relationship between different dimensions of service quality in the context of the increasing digital marketing volume. With the transition to Industry 5.0 and the Covid 19 pandemic process, the importance of quality service provision and CRM services in the digital environment has begun to be understood better. In the study, answers to some research questions are sought with two different models. Model 1 researches whether there is a relationship between reliability, enthusiasm, sensitivity, concrete qualities, and trust and whether trust affects customer satisfaction positively. Model 2 researches whether there is a significant relationship between reliability-enthusiasm, trust-enthusiasm, enthusiasm, sensitivity, trust-concrete features, enthusiasm-concrete features, and concrete features and customer satisfaction.

The study begins with the literature review and hypothesis testing. Then, the importance of information and communication technologies for organizations in the digital age was emphasized. In the methodology section, there are research design and sample, research profile and scale sections. Theoretical and managerial implications are examined under a 
separate heading. The study ends with the limitations and suggestions for future research and the conclusion.

\section{Literature review and hypothesis test}

Service quality is calculated according to the SERVQUAL scale by subtracting expectations from the expected performance scores. Participants are asked to rate their expectations first, and then the performance of a particular organization is interpreted (Landrum \& Prybutok, 2004, p. 629). In the SERVQUAL model, the tangible features (tangibles) are the building vehicle and personnel view. Reliability is the ability of the firm to perform the service. Enthusiasm is the willingness to assist the customers. Assurance (trust) is the knowledge and kindness of the firm staff. Responsiveness (empathy) explains employees putting themselves in the exchange of customers (Parasuraman et al., 1988). Trust reflects the customer's trust in the firm's good faith and their belief in the company's competence. Reliability is largely about whether the outcome of the service delivery is as promised. The other four dimensions are related to the service delivery process (Hu et al. 2009, p. 112).

There is a consensus that service quality is different from customer satisfaction. For example, a customer may be satisfied with the bank's services, but may also feel that the bank is providing poor service. Some people may see customer satisfaction as a premise of service quality. Parasuraman et al. (1988) see the gap between performance and expectation as the basis for measuring service quality (Robinson, 1999, p. 23). Studies on service quality and customer satisfaction are usually done separately, only a few researchers have examined both together (Robinson, 1999, p. 29). Service quality expectations are the ideal thing that a customer expects from an excellent company. It believes that customer expectations will come true in satisfaction. Satisfaction considerations require customer experience, while for quality this is not (Caruana et al., 2000, pp. 1341-1342). It is imperative to understand the role of quality and costs in customer evaluations and their relationship to satisfaction and post-purchase behaviour to increase customer satisfaction and loyalty and to design effective strategies. There are two conceptualizations about satisfaction. The first admits that satisfaction is determined by a cognitive process that compares what the customer receives with what they give up to obtain service. Second, it sees satisfaction as a sensory feeling resulting from the evaluation process (Tam, 2004, p. 899). The more customers perceive that the service quality exceeds the cost of receiving the service, the higher it will be. This results in more satisfaction (Tam, 2004, p. 902). Perceived service quality is a global judgment or attitude about the superiority of service, whereas satisfaction is related to a particular process (Parasuraman et al., 1988, p. 16) Customer satisfaction is seen as a cognitive or emotional response that occurs in response to single or long-term service comparisons (Hu et al., 2009, p. 115).

The increasing importance of information technologies has led researchers to understand how their customers evaluate information technology-based services and how they affect the service provider's perceptions of service quality and customer satisfaction. Service quality is affected by and affects some variables such as value, attitude, expectations, and desires. These variables can guide purchasing behaviour and financial performance. In this context, 
it is useful to develop a theoretical framework to establish clear links between the various variables (Seth et al., 2005, pp. 933-939).

The customer satisfaction model, based on the expectation-disconfirmation theory, argues that customers are satisfied when past expectations are met or the firm's performance is accepted. Negative approval occurs when the product or service performance is worse than expected (Rather et al., 2019a, p. 203).

From here two models were tested in the study. We propose the hypotheses of the first model:

H1a: Reliability affects Enthusiasm positively.

H1b: Enthusiasm affects sensitivity positively.

H1c: Sensitivity affects concrete features positively.

H1d: Concrete features affect trust positively.

H1e: Trust affects customer satisfaction positively.

We propose that the hypotheses generated in the second model are as follows:

H2a: Reliability affects Enthusiasm positively.

H2b: Trust affects Enthusiasm positively.

H2c: Enthusiasm affects sensitivity positively.

H2d: Trust affects sensitivity positively.

H2e: Sensitivity affects concrete features positively.

H2f: Trust affects concrete features positively.

H2g: Enthusiasm affects concrete features positively.

H2h: Sensitivity affects customer satisfaction positively.

H21: Concrete features affect customer satisfaction positively.

\section{The importance of information and communication technologies for the organizations in the digital age}

The digital age in which the world enters is connecting objects with objects, people with objects, and people with people. This increased the value of the available data. Access to large amounts of data has enabled companies to generate more value and improve value propositions (Banner, 2018, p. 13). Digitalization also symbolizes the transition from a productcentric business model to a service-centric model. New information technologies have made the most important developments in the field of interactivity and it has led to a shift from mass marketing to individual marketing, which guides each customer's needs individually (Muther, 2002, p. 91; Matzner \& Büttgen, 2018, p. 7). This transformation allowed companies to provide additional services or to replace their products with services (replacing software products with cloud-based software as a service). Digitization at the micro or company level has affected service management, which performs tasks or jobs that involve the leadership processes required during digital transformation (Matzner \& Büttgen, 2018, p. 7). The service sector is at the heart of a successful digital transformation. The overall goal of any transformation, including the service sector, is to increase productivity and creativity in matters such as decision making, innovation, and growth, commitment to goals. Transformation allows organizations to direct market requirements much faster; it enables cooperation in informa- 
tion sharing. Digital transformation is applied equally to the operations of service systems, to internal and external customers (Demirkan \& Spohrer, 2018, p. 12). Digital transformation makes it possible to mobilize resources specifically for specific purposes and it ensures that it does not necessarily focus on anything other than the necessary actions (Fritzsche \& Ng, 2018, p. 15). Digital transformation is presented as a solution to organizational problems related to efficiency and effectiveness. The increase in the global population has required the digital transformation of organizations. Changing processes and activities have necessitated the use of more digital technology. There have been many consequences and costs of making forward-looking forecasts with artificial intelligence. Digitalization and digital transformation have been practiced in organizations since the 1950s. Between 1943 and 1958, computers pioneered computing, decision support, and computing processes; but the gains were not enough. The 1960s saw some production robots, online processing, and time-sharing. In the mid-1970s, the personal computer revolution began. Advances in information technologies since the 1960s have transformed institutions internally and externally. Internal changes included early versions of transactional orientation systems. In the 1980s, the computer began to perform the tasks performed by the office workers and the business processes were redesigned. External changes emphasize the transformation of the communication process in business-customer relations following the emergence of the internet in the 1990s (Ortiz et al., 2019 , p. 2). The 1990s introduced local area networks, the global Internet, data warehouses, digital data storage, and digital telephones into the service of managers. The 2000 s predicted mobile phones, faster parallel processing, computing, storage, and sharing of digital cellular networks. Digital data storage and computing capabilities have increased exponentially in 2010 (Heavin \& Power, 2018, pp. 38-39). The revolution in information technology and the competitive structure of the global economy encouraged the creation of new values for customers. New forms of value creation have expanded and enriched mobile technologies (Ortiz et al., 2019, p. 2).

Digital technologies require us to radically change our behaviors and rediscover market relations. Digital transformation is more extensive than technology. It's about processes, strategy, culture, behavior, and people. It covers comprehensive and fundamental changes to the functioning of the organization (Perkin \& Abraham, 2017, pp. 31-50).

A three-step process for digital transformation can be foreseen (Perkin \& Abraham, 2017, p. 52):

1-Legacy: Digital transformation should be carried out by determining what types of traditional ideas and approaches will continue to exist.

2-Enabling: Organizations have made a fundamental shift in mind set in strategy, process, resources, and culture, but efforts are underway to maintain these new elements.

3. Naturalism: Organizations work in harmony with the changing environment and this situation is fully reflected in the organization's functioning, organizational culture.

Digital organizations are useful because the information needed to support business functions can be accessed at any time and place. Hierarchy and organizational levels exist in digital firms. Digital firms develop optimal hierarchies; decentralize the decision-making process, defined by a flatter organizational structure. Digital firms establish an inter-organizational system between suppliers, customers, and even competitors. For example, Cisco Systems does 
not produce its network products. It uses other companies such as Flextronics. It transmits its orders to Flextronics and monitors its status when the order is shipped (Laudon \& Laudon, 2017, pp. 5-21).

Digital transformation must be encouraged and supported by the top management of the organization. This person may be a board member, director of the transformation, or chairman of the digital board responsible for running the change process. Digital transformation requires leaders, especially those with strong intelligence, with knowledge of data and processes and exhibits about uncertainties. The leader accelerates the change plan to increase organizational momentum, breaking employees' resistance to change. He aims at a competitive advantage as well as consolidated earnings. Leadership should promote and develop a data-based culture. Transformation begins with strategic leadership and requires an organizational strategy (Heavin \& Power, 2018, p. 41; Seijts \& Gandz, 2018, p. 246; Rajola, 2003, p. 238). The focal point of the digital transformation is to support the vision, strategy, and execution process with different applications, enabling the exchange of environment and culture. It is important to be an agile organization in digital transformation, to aim for long-term change, to display a stable determination (Rajola, 2003, p. 259). Strategic, tactical, and operational tasks are within the scope of digital transformation, and transformation requires stability in the successful execution of tasks. Strategic tasks consist of activities for the implementation of digital transformation strategies. Tactical tasks are complementary to the success of the transformation strategy. Operational tasks are based on technology selection and development, establishing valid data integration platforms. To do this, the necessary security controls are selected, balancing data access to data protection. It is based on defining and developing the capabilities required for achieving a digital vision. A strategic vision is useful for digital transformation, but it has to be based on customer needs and technological possibilities. Managers aim to go beyond original technologies to develop a comprehensive digital technology capability with a well-defined transformation strategy (Heavin \& Power, 2018, p. 42).

The following figure shows the execution of digital transformation tasks (Heavin \& Power, 2018, p. 42):

Digital Transformation Maturity

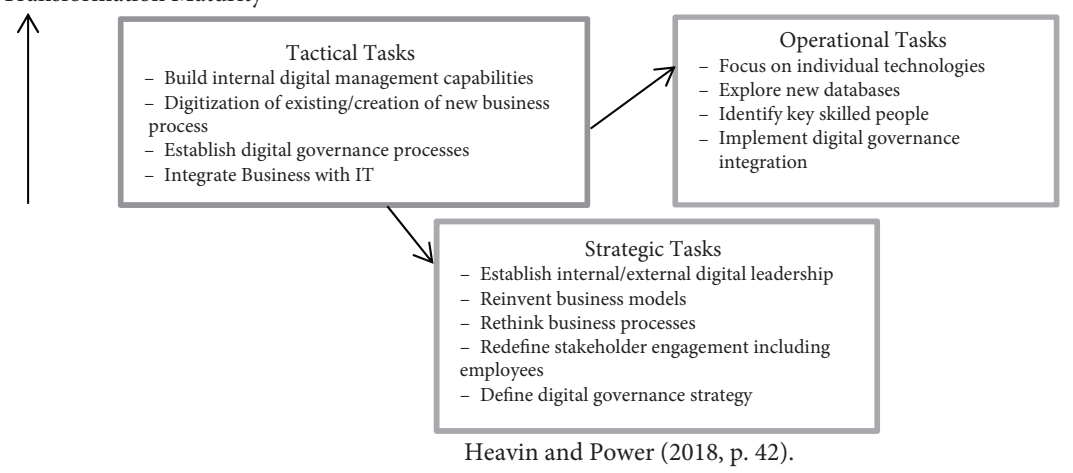

Value

Figure 1. Digital transformation tasks 
As seen in Figure 1, tactical tasks tend to strengthen the digital functionality of the organization and directly affect the operational and strategic tasks within the organizational system. Digital initiatives have been strengthened by the expansion of information communication systems that combine three major types of technology. These three types are virtual systems (such as cloud computing), mobile systems (social media, internet of things, smartphones and tablets, Web 2.0), and built-in analytical systems (such as big data). These technologies integrate with the integrated back-office information communication technologies systems that make the digital initiative possible. From the production perspective, digital technologies lead to the customization of products and services, ultimately leading to mass customization (Loonam et al., 2018, p. 102). The term Web 2.0 in these technologies was used in 2004 to describe end-users and software developers who want to take advantage of the World Wide Web. Accordingly, the content and platform will be organized by all users in a participatory manner, rather than being created and published by individuals. Since Web 2.0 represents ideological and technological resources, content produced by users can be seen as a result of individuals using social media (Kaplan \& Haenlein, 2010, p. 61). The Internet of things (IoT), on the other hand, has found a widespread application because it removes technical barriers with its automatic control system and significantly reduces costs. Products connected with the Internet of Things provide opportunities for the presentation of combinations of products and services adapted to each market and customer (Saarikko et al., 2017, pp. 670-674). Big data is a new technology paradigm in which data is produced at high speed and with high volume and diversity. Technological advances in big data infrastructure enable companies to transform themselves into data-oriented organizations. During this period, web mining techniques were developed to analyze users' online activities. During the Big Data 2.0 (2005-2014) period, companies used social media analyses to organize effective marketing campaigns for their target audience. Big Data 3.0 (2015) includes Internet of Things applications that generate data such as pictures, audio, video. It offers companies great potential in creating new jobs, developing products and services, and modernizing business applications. Using big data from multiple sources, companies offer personalized product/service recommendations and other promotional offers (Lee, 2017, pp. 293-299). Identifying the necessary strategies through digital transformation has affected organizations in four dimensions: the use of technology, changes in value creation, structural changes, and financial situations. The use of technology affects the ability of companies to benefit from technology and guides their attitude towards new technologies. The use of new technologies from a business perspective emphasizes changes in value creation. These relate to digital transformation strategies in firms' value chains (such as how far new digital activities are away from classical processes). Structural changes are needed to provide the basis for new processes with different technologies in use and different types of value creation. Structural changes emphasize variations in the organizational structure of the firm, in particular dealing with the location of new physical activities within institutional structures. The previous three dimensions can be transformed after financial situations are taken into account. These include the organization's ability to act by reducing its internal activities and to fund digital transformation efforts. Financial conditions are the initiator and driving force of change (Matt et al., 2015, pp. 340-341). 


\section{Methodology}

\subsection{Research design and sample}

Although quantitative and qualitative researches implemented at the company level are common in the literature, this research focused on the customer satisfaction factor and used a questionnaire based on quantitative analysis through face-to-face communication. As a result of the qualitative research conducted by Ortiz et al. (2019, p. 7), it is concluded that technologies can provide a competitive advantage in the cost structure of business provided that organizations are supported by the general information technology system. Another conclusion reached is that mobile technology initiatives related to customers will make a difference in marketing. Face-to-face technological communication with customers should be supported by administrative and administrative steps. In addition to technological capabilities, technological orientation has also gained importance for firms. Technological capability depends on the capacity of a firm to benefit from and apply technical knowledge and to use its capabilities to create new products and processes. Technological orientation, on the other hand, emphasizes the ability of the company's resources to be devoted to research and development and the ability to benefit from them by developing new technologies (Hsu et al., 2014, pp. 460-51). Hsu et al. (2014, pp. 51-53) showed that the positive effect of technological orientation on technological ability and performance was determined. Technological orientation positively affects market performance. Technological capabilities mediate the relationship between technological orientation and market performance. Technological orientation and technological capabilities also affect financial performance through market performance. According to Roach et al. (2018, p. 567), market orientation combines technological development-related competencies with technical integration capabilities and increases the ability of market-focused firms to create value for their customers through innovations. The random sample was used to determine how much of the digital services in a developing country benefited from and the perceptual characteristics of this population regarding the service. No changes have been made to the adaptation model. The survey was conducted in Turkish. To avoid response bias, care was taken to ensure that the people surveyed were from different sectors.

\subsection{Research profile and measurement scales}

In line with this literature, the model of the study consists of 5 independent variables and 1 dependent variable which affect the service quality. The study aims to measure the satisfaction of the participants with different demographic characteristics from the companies they communicate with according to the concrete features, enthusiasm, trust, and sensitivity variables that constitute the digital service quality. In the study, 22 questions developed by Parasuraman et al. (1988) were directed to 405 people living in Kocaeli province as a five-point Likert-type scale question between December 2018 and August 2019. An online questionnaire was sent to the entire population. It was determined that 350 people completed the questionnaire completely. The response rate of the survey was $86 \%$. A random sampling method from the entire population was used in the survey application. Open-ended ques- 
tions were not used in the questionnaire. All the measurement scales used in this study were adapted from earlier studies. Questions were developed on a 5-point Likert scale ranging from 5 (strongly agree) to 1 (strongly disagree). Closed-ended questions were asked to the participants. Inspired by the study of Karadeniz and Gözüyukarı (2015), the participants were asked four questions about customer satisfaction. The data collected as a result of the survey was analyzed with SPSS 25 statistical program. The validity and significance of the developed model were tested with LISREL structural equation model. To test the validity of the multidimensional research model, confirmatory factor analysis was applied using maximum probability estimation. However, there is no consensus in the literature about the analysis of the structural equation model to be used to evaluate the appropriate model for confirmatory factor analysis. The square root of RMSEA is less than 0.05 and less than 0.08 indicates an acceptable fitness (Hooper et al., 2008; Schermelleh-Engel et al., 2003). Reliability is the ability of companies to perform a service accurately and reliably. Enthusiasm or enthusiasm is the willingness to assist the customer and deliver the service quickly. Trust is that the business staff is sophisticated and kind, and can inspire a sense of trust in the customers. The sensitivity is that employees put themselves in the place of customers, giving customers personal attention.

\subsection{Research profile}

Respondents are those who benefit widely from businesses that provide services to business markets and customer markets. The survey promised that the individual answers to the respondents would remain confidential and that only the results would be reported. Digital CRM capabilities were operationalized using a scale adapted from Parasuraman et al. (1988). The scale items have been specifically modified to access customer information using digital CRM applications. The covariance-based structural equation model used in the study followed a two-stage process to determine the measurement characteristics of the linear effects of the research model and hypotheses. In the first stage, a measurement model was identified and adapted. In the second stage, the suitability of the structural model to the data was tested (Trainor et al., 2014, p. 1205). Of the respondents, $54.0 \%$ are female, $62.3 \%$ are single, $29.1 \%$ are $40-49$ years old, $42.9 \%$ are high school graduates, $47.4 \%$ are working in the private sector, and $34.6 \%$ an income of 501-1000\$. The high proportion of customers communicating with the technology sector provides a better assessment of the analysis results. Also, most of the surveyed customers (89.2\%) had a high level of education. Participants represent the workforce actively involved in the business.

The validity and reliability of the questionnaire were tested primarily. The reliability level of Service Quality and Satisfaction scales is very high (CA > 0.800).

\subsection{Common method variance}

In the study, there is a possibility of common method variance because reliability, enthusiasm, sensitivity, concrete features, and trust variables are evaluated with the same scale, at the same time, and by the same people. The most common method to determine this is Harman's single factor test (Podsakoff et al., 2003, p. 889). In this context, all items used in 
measuring variables were subjected to non-cyclic factor analysis. As a result of the analysis, a total of 5 dimensions with eigenvalues higher than 1 were determined. The first dimension explains 0.388 of the total variance, the second dimension explains 0.163 of the total variance, the third dimension explains 0.093 of the total variance, the fourth dimension explains 0.050 of the total variance, and the fifth dimension explains 0.047 of the total variance (Table 1). The results obtained show that there is no common method variance problem in the study.

Table 1. Reliability results quality of service and of customer satisfaction scores

\begin{tabular}{|l|c|c|c|}
\hline & AVE & CR & Cronbach's Alpha \\
\hline Reliability & 0.962 & 0.990 & 0.966 \\
\hline Concrete Features & 0.959 & 0.990 & 0.990 \\
\hline Enthusiasm & 0.938 & 0.984 & 0.989 \\
\hline Trust & 0.888 & 0.969 & 0.981 \\
\hline Sensitivity & 0.952 & 0.988 & 0.987 \\
\hline Customer Satisfaction & 0.958 & 0.989 & 0.990 \\
\hline
\end{tabular}

Table 2. Demographic features

\begin{tabular}{|c|c|c|}
\hline & $\mathrm{n}$ & $\%$ \\
\hline \multicolumn{3}{|l|}{ Gender } \\
\hline Female & 189 & 54.0 \\
\hline Man & 161 & 46.0 \\
\hline \multicolumn{3}{|l|}{ Marital Status } \\
\hline Married & 132 & 37.7 \\
\hline Single & 218 & 62.3 \\
\hline \multicolumn{3}{|l|}{ Age } \\
\hline $18-29$ & 75 & 21.4 \\
\hline $30-39$ & 98 & 28.0 \\
\hline $40-49$ & 102 & 29.1 \\
\hline$>50$ & 75 & 21.4 \\
\hline \multicolumn{3}{|l|}{ Education Status } \\
\hline Elementary / Middle School & 38 & 10.9 \\
\hline High School & 150 & 42.9 \\
\hline Pre-License & 120 & 34.3 \\
\hline License & 42 & 12.0 \\
\hline $\mathrm{PhD}$ & 0 & 0.0 \\
\hline \multicolumn{3}{|l|}{ Job } \\
\hline Public Sector & 136 & 38.9 \\
\hline Private Sector & 166 & 47.4 \\
\hline Student & 38 & 10.9 \\
\hline Retired & 10 & 2.9 \\
\hline Unemployed & 0 & 0.0 \\
\hline \multicolumn{3}{|l|}{ Income (\$) } \\
\hline $0-500$ & 38 & 10.9 \\
\hline $501-1000$ & 121 & 34.6 \\
\hline $1001-2000$ & 113 & 32.3 \\
\hline$>2501$ & 78 & 22.3 \\
\hline
\end{tabular}


$54.0 \%$ of the respondents are women, $62.3 \%$ are single, $29.1 \%$ are $40-49$ years old, $42.9 \%$ are high school graduates, $47.4 \%$ are working in the private sector, 34.6 of them have an income of 1501-3000 TL (Table 2).

Table 3. Services sectors in which participants communicate

\begin{tabular}{|l|c|c|}
\hline & $\mathrm{n}$ & $\%$ \\
\hline Retail & 66 & 18.9 \\
\hline Technology & 91 & 26.0 \\
\hline Transportation & 23 & 6.6 \\
\hline Health & 38 & 10.9 \\
\hline White Goods & 86 & 24.6 \\
\hline Build & 18 & 5.1 \\
\hline Education & 23 & 6.6 \\
\hline Other & 5 & 1.4 \\
\hline
\end{tabular}

When the sectors of the firm are examined, the participants communicate with the most technology companies with a rate of $26.0 \%$. They were contacted with the least construction companies with a rate of $5.1 \%$ (Table 3).

According to Pearson Correlation analysis; the relationship between Quality of Service dimensions and satisfaction is statistically significant, positive, and very strong. There is a mutual relationship between the independent variables. There is also a linear relationship between the dependent variable and the independent variable (Table 4).

Table 4. Relationship between service quality dimensions and customer satisfaction

\begin{tabular}{|l|c|c|c|c|c|c|c|}
\hline & Average & $\begin{array}{c}\text { Reli- } \\
\text { ability }\end{array}$ & $\begin{array}{c}\text { Concrete } \\
\text { Features }\end{array}$ & $\begin{array}{c}\text { Enthu- } \\
\text { siasm }\end{array}$ & Trust & $\begin{array}{c}\text { Sensi- } \\
\text { tivity }\end{array}$ & $\begin{array}{c}\text { Customer } \\
\text { Satis- } \\
\text { faction }\end{array}$ \\
\hline Reliability & 3.19 & 1 & & & & & \\
\hline Concrete Features & 3.41 &. $\mathbf{9 7 6}$ & 1 & & & & \\
\hline Enthusiasm & 3.64 & $.959^{* *}$ & $.977^{* *}$ & 1 & & & \\
\hline Trust & 3.58 & $.956^{* *}$ & $.986^{* *}$ & $\mathbf{. 9 8 9}^{* *}$ & 1 & & \\
\hline Sensitivity & 3.54 & $.964^{* *}$ & $.986^{* *}$ & $.993^{* *}$ & $\mathbf{. 9 9 2}^{* *}$ & 1 & \\
\hline Customer Satisfaction & 3.63 & $.940^{* *}$ & $.970^{* *}$ & $.991^{* *}$ & $.991^{* *}$ &. $\mathbf{9 8 6}^{* *}$ & 1 \\
\hline
\end{tabular}

Note: ${ }^{* *} \mathrm{p}<0.01$ significant.

The validity of the factor structures was examined by Confirmatory Factor Analysis of the scales. CFA is applied more theoretically and is often used to test obvious hypotheses. CFA provides the researcher with solutions for the relationship networks that he does not consider, thus contributing to the research on a more strong foundation. The standardized regression coefficients of the quality of service and customer satisfaction scale and the conditions for providing fitness indexes are indicated in the table below. The results show that 
meaningful inferences can be made from a model to be tested according to confirmatory factor analysis (Table 5).

Table 5. CFA results of quality of service scale

\begin{tabular}{|l|c|}
\hline \multicolumn{1}{|c|}{ Acceptable Fit Indices } & Calculated Fit Indices \\
\hline$\chi 2 /$ sd $<5$ & 1.7041 \\
\hline GFI $>0.90$ & 0.556 \\
\hline AGFI $>0.90$ & 0.398 \\
\hline CFI $>0.90$ & 0.889 \\
\hline RMR & 0.026 \\
\hline RMSEA $<0.08$ & 0.214 \\
\hline
\end{tabular}

Table 6. CFA results of the customer satisfaction scale

\begin{tabular}{|l|c|}
\hline \multicolumn{1}{|c|}{ Acceptable Fit Indices } & Calculated Fit Indices \\
\hline$\chi 2 /$ sd $<5$ & 5.387 \\
\hline GFI $>0.90$ & 0.992 \\
\hline AGFI $>0.90$ & 0.924 \\
\hline CFI $>0.90$ & 0.999 \\
\hline RMR & 0.002 \\
\hline RMSEA $<0.08$ & 0.112 \\
\hline
\end{tabular}

The results of the fit indices of the first model developed are positive. The GFI statistic is between 0 and 1 and values close to 1 indicate good fit (GFI >0.992). AGFI is valued in the range 0 to 1 but shows good alignment as it approaches 1 . Good alignment for AGFI values above 0.90 or 0.95 is mentioned. Also, 0.90 for this index shows the determinant good fit relative to the basic model, while values greater than 0.85 are also an acceptable fit value (AGFI > 0.924). RMR takes a value between 0 and 1 . The RMR value will indicate a good fit as it approaches 0 . It is a bad fit index, higher values indicate bad fit ( $R M R=0.026$ and 0.002). For the RMSEA, which is known as the poor fit index and where the value of 0 shows excellent fit, values below 0.05 indicate a good fit. (RMSEA $=0.214$ and 0.114 ) (Table 6).

\section{Discussion}

Since digital innovations have a high risk of uncertainty for customers, customers' satisfaction with the products and services offered at the organizational level has gained importance. Within the scope of this study, it is being investigated how digital innovation affects the satisfaction of customers such as searching for information, purchasing, consuming, speaking, and sharing their experiences about products and services (Sahut et al., 2019, p. 2).

For Model 1, the $\mathrm{x} 2 / \mathrm{sd}$ ratio is less than 5 and is an acceptable value. RMSEA is below 0.05 (0.227). This shows that the model has a good fit. RMR ratio is very close to $0(0.029)$. The CFI is between 0 and $1(0.847)$ and is very high for the model (Table 7$)$. 
Table 7. Model 1 SEM analysis results

\begin{tabular}{|l|c|}
\hline \multicolumn{1}{|c|}{ Acceptable Fit Indices } & Calculated Fit Indices \\
\hline$\chi 2 /$ sd $<5$ & 1.8954 \\
\hline GFI $>0.90$ & 0.455 \\
\hline AGFI $>0.90$ & 0.325 \\
\hline CFI $>0.90$ & 0.847 \\
\hline RMR & 0.029 \\
\hline RMSEA $<0.08$ & 0.227 \\
\hline
\end{tabular}

According to the results, reliability affects enthusiasm $(\beta=0.981)$. Enthusiasm affects sensitivity $(\beta=1.003)$. Sensitivity affects concrete features $(\beta=1.000)$. Concrete features affect trust $(\beta=0.996)$. Trust affects customer satisfaction $(\beta=1.001)$. All hypotheses are accepted within Model 1 (Figure 2).

For Model 2, the $\mathrm{x} 2 / \mathrm{sd}$ ratio is below 5 and is an acceptable value. The RMSEA value is below 0.05 (0.237). This shows that the model has a good fit. The CFI value is close to 1 (0.835) (Table 8 and Table 9).

Reliability $(\beta=0.238)$ and trust $(\beta=0.973)$ positively affect Enthusiasm $(p<0.05)$. Enthusiasm $(\beta=1,138)$ positively affects sensitivity, but trust affects sensitivity negatively $(\beta=-0.140)$. Sensitivity $(\beta=-1.201)$ and trust $(\beta=-1.019)$ affect the concrete features negatively, but enthusiasm $(\beta=4.865)$ affects the positive $(p<0.05)$. Sensitivity $(\beta=1.309)$ affects customer satisfaction positively, but concrete features $(\beta=-0.477)$ affect negative.

In the final phase of the study, the effect of enthusiasm and reliability on independent variable customer satisfaction has been tested, and it is assumed that enthusiasm and reliability positively affect customer satisfaction (Table 10 and Figure 3).

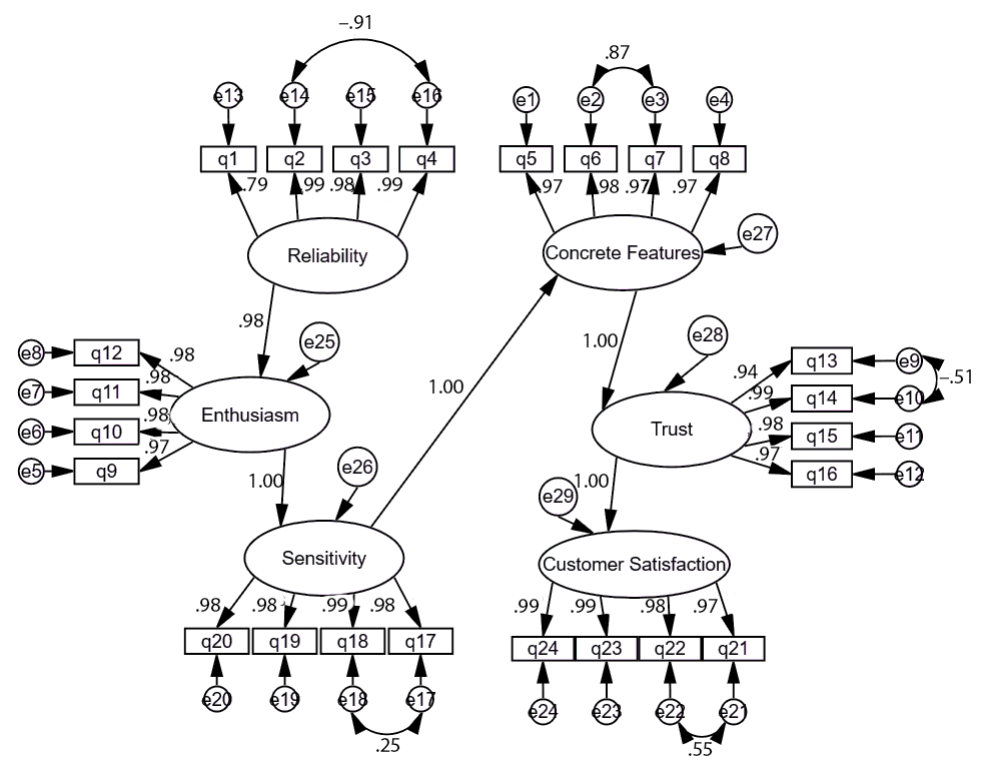

Figure 2. Model 1 SEM analysis 
Table 8. Model 1 SEM analysis standardized regression coefficients and conditions for providing fit indices

\begin{tabular}{|l|l|c|c|c|l|}
\hline \multicolumn{1}{|c|}{$\begin{array}{c}\text { Dependent } \\
\text { Variable }\end{array}$} & $\begin{array}{c}\text { Independent } \\
\text { Variable }\end{array}$ & $\mathrm{B}$ & $\mathrm{T}$ & $\mathrm{P}$ & \multicolumn{1}{c|}{$\begin{array}{c}\text { Acceptance } \\
\text { Status }\end{array}$} \\
\hline Enthusiasm & Reliability & 0.981 & 22.131 & $0.000^{\star}$ & Accept \\
\hline Sensitivity & Enthusiasm & 1.003 & 55.036 & $0.000^{\star}$ & Accept \\
\hline $\begin{array}{l}\text { Concrete } \\
\text { Features }\end{array}$ & Sensitivity & 1.000 & 57.909 & $0.000^{\star}$ & Accept \\
\hline Trust & $\begin{array}{l}\text { Concrete } \\
\text { Features }\end{array}$ & 0.996 & 41.373 & $0.000^{\star}$ & Accept \\
\hline $\begin{array}{l}\text { Customer } \\
\text { Satisfaction }\end{array}$ & Trust & 1.001 & 40.982 & $0.000^{\star}$ & Accept \\
\hline
\end{tabular}

Note: ${ }^{\star} \mathrm{p}<0.05,{ }^{* *} \mathrm{p}<0.001$ significant.

Table 9. Model 2 SEM analysis results

\begin{tabular}{|l|c|}
\hline \multicolumn{1}{|c|}{ Acceptable Fit Indices } & Calculated Fit Indices \\
\hline$\chi 2 /$ sd $<5$ & 2.656 \\
\hline GFI $>0.90$ & 0.500 \\
\hline AGFI $>0.90$ & 0.370 \\
\hline CFI $>0.90$ & 0.835 \\
\hline RMR & 0.975 \\
\hline RMSEA $<0.08$ & 0.237 \\
\hline
\end{tabular}

Table 10. Model 2 SEM analysis standardized regression coefficients and conditions for providing fit indexes

\begin{tabular}{|l|l|c|c|c|l|}
\hline $\begin{array}{c}\text { Dependent } \\
\text { Variable }\end{array}$ & $\begin{array}{c}\text { Independent } \\
\text { Variable }\end{array}$ & $\beta$ & $\mathrm{t}$ & $\mathrm{p}$ & $\begin{array}{c}\text { Acceptance } \\
\text { Status }\end{array}$ \\
\hline Enthusiasm & Reliability & 0.238 & 18.063 & $0.000^{*}$ & Accept \\
\hline Enthusiasm & Trust & 0.973 & 37.08 & $0.000^{\star}$ & Accept \\
\hline Sensitivity & Enthusiasm & 1.138 & 24.654 & $0.000^{*}$ & Accept \\
\hline Sensitivity & Trust & -0.140 & -3.474 & $0.000^{\star}$ & Accept \\
\hline $\begin{array}{l}\text { Concrete } \\
\text { Features }\end{array}$ & Sensitivity & -1.201 & -4.021 & $0.000^{*}$ & Reject \\
\hline $\begin{array}{l}\text { Concrete } \\
\text { Features }\end{array}$ & Trust & -3.019 & -15.303 & $0.000^{*}$ & Reject \\
\hline $\begin{array}{l}\text { Concrete } \\
\text { Features }\end{array}$ & Enthusiasm & 4.865 & 11.343 & $0.000^{*}$ & Accept \\
\hline $\begin{array}{l}\text { Customer } \\
\text { Satisfaction }\end{array}$ & Sensitivity & 1.309 & 45.545 & $0.000^{*}$ & Accept \\
\hline $\begin{array}{l}\text { Customer } \\
\text { Satisfaction }\end{array}$ & $\begin{array}{l}\text { Concrete } \\
\text { Features }\end{array}$ & -0.477 & -22.987 & $0.000^{*}$ & Reject \\
\hline
\end{tabular}

Note: ${ }^{*} \mathrm{p}<0.05,{ }^{* *} \mathrm{p}<0.001$ significant. 


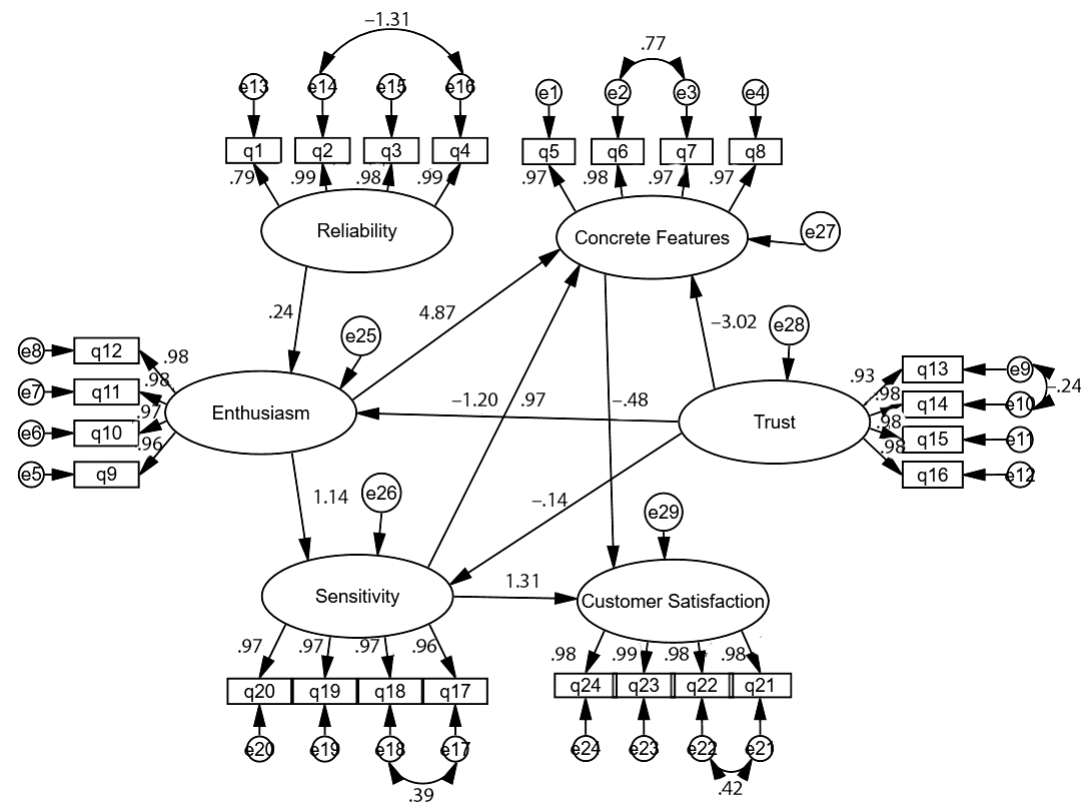

Figure 3. Model 2 SEM analysis

Table 11. Customer satisfaction-enthusiasm and reliability relationships

\begin{tabular}{|l|l|c|c|c|l|}
\hline \multicolumn{1}{|c|}{$\begin{array}{c}\text { Dependent } \\
\text { Variable }\end{array}$} & $\begin{array}{c}\text { Independent } \\
\text { Variable }\end{array}$ & $\beta$ & $\mathrm{t}$ & $\mathrm{p}$ & \multicolumn{1}{|c|}{$\begin{array}{c}\text { Acceptance } \\
\text { Status }\end{array}$} \\
\hline $\begin{array}{l}\text { Customer } \\
\text { Satisfaction }\end{array}$ & Enthusiasm & 0.582 & 56.893 & $0.000^{*}$ & Accept \\
\hline $\begin{array}{l}\text { Customer } \\
\text { Satisfaction }\end{array}$ & Reliability & -0.248 & -21.011 & $0.000^{*}$ & Reject \\
\hline
\end{tabular}

Note: ${ }^{*} \mathrm{p}<0.05,{ }^{* *} \mathrm{p}<0.001$ significant.

While enthusiasm affects customer satisfaction positively $(\beta=0.582)$, reliability affects negatively $(\beta=-0.248)$. When theoretical conceptualization and measurements related to digital CRM capabilities are taken into consideration as a resource, it is seen that trust, sensitivity, and enthusiasm positively affect customer satisfaction. It has become important for digital technologies to provide services to companies to better meet the needs of customers. This suggests that third-party databases are becoming increasingly important. Customers and vendors will be more dependent on portals. The portals will be operational and informational tools for vendors to determine customer satisfaction. The portals will ensure two-way interaction and communication planning with customers. Customers will define their information requirements with access to digital channels. Implementing the CRM system requires a change in different areas of the business and an appropriate balance between people, processes, and technology. Digital CRM initiatives should be developed based on a vision. Also, every staff in the organization has to understand the changes that CRM will bring (Table 11). 
Other academic studies in the literature show the validity of our study. The study by Landrum and Prybutok (2004, pp. 631-634) shows that service quality, information quality, and system quality affect product usefulness and satisfaction. As a result of the questionnaire, 385 responses were analyzed. Participants emphasized the importance of sensitivity at first level. When the participants were asked to score each dimension, the mean of reliability and sensitivity dimensions was high. Caruana et al. (2000, p. 1348), 80 personal interviews were conducted in four weeks. The analysis showed that customer satisfaction, value, and service quality are related. Just as the value given to service has an intermediary effect on satisfaction, service quality also has a direct effect on satisfaction. The results are that although customers believe in high service quality, it does not increase satisfaction. Satisfaction alone does not depend on service quality. Another survey conducted by Caruana (2002, p. 818) consists of 37 items measuring service loyalty, service quality, and customer satisfaction. It was applied to 1000 people with a $20.5 \%$ reply approval. It has been determined that service quality affects service loyalty through customer satisfaction. It was found that service quality is an important input for customer satisfaction and explains 53\% of the total variance.

Research conducted by Rather and Hollebeek (2019, p. 1436) also addresses the positive effect of satisfaction on service utilization, positive communication, and dividends. As a result, it was observed that customer satisfaction with loyalty, trust, and loyalty significantly affects brand identity. Brand identity, loyalty, trust, and satisfaction were found to have a positive effect on loyalty. The research was conducted with 345 people in 6 cities of India. Raza et al. (2020, p. 10), 400 questionnaires were distributed throughout the research and 280 of them were analyzed. The research was conducted in three cities of Pakistan and the banking sector. According to the research results; the Social responsibility behavior of banks positively affects customers' perception of electronic service quality (Raza et al. 2020, p. 12).

Within the scope of the research conducted by Rather (2020, pp. 22-26), 520 questionnaires were conducted with a response rate of $83.67 \%$. The study found that customer experience and identification mediate relationships between customer involvement (cognitive, sensory, behavioural) and behavioural intentions. In particular, customer experience mediated the effects of cognitive engagement on behavioural intentions.

The research executed by Tam (2004, pp. 908-910) was realized among Chinese consumers in Hong Kong in the People's Republic of China. Family/popular restaurant chains that offer table service and extensive menus were selected for the study. The number of restaurants used in the analysis was 209. As a result, it was found that perceived service quality has a positive effect on customer satisfaction and perceived value. As the perception of the customers about the quality of the service increased, it was revealed that they were more satisfied with the service. The more satisfied customers are with the service, the more likely they are to repurchase and encourage others to buy the service. To encourage customers' repetitive purchasing behaviour, firms should design strategies to improve customer perceptions of service value.

Data in another study were collected through a survey conducted in various parts of four and five-star hotels in six cities of India. 345 usable responses were collected from the 400 questionnaires. The study revealed that brand identity has an impact on satisfaction, customer loyalty, brand loyalty, and brand trust. The results show that companies play a valuable 
role in the daily lives of customers and can be instrumental in the formation of individual identity. Customer satisfaction has been identified as a basic precondition for the development of trust and loyalty (Rather, 2018a, pp. 498-506).

Kuo et al. (2009, pp. 887-894) examined the relationships between service quality, perceived value, customer satisfaction, and post-purchase intention to evaluate the service quality of mobile valued services. Data were collected from students of 15 major universities in Taiwan. 387 valid questionnaires were evaluated. According to the main findings, service quality positively affected both perceived value and customer satisfaction. Service quality indirectly has a positive impact on post-purchase intention through customer satisfaction or perceived value. Among the dimensions of service quality, customer service and system reliability are the most effective on perceived value and customer satisfaction, and the effect of content quality is second.

Huang et al. (2019, pp 1456-1460) in SGS Taiwan Lab, 302 questionnaires were answered, 13 of them were eliminated. Regression analysis was performed to examine whether the service quality affects customer satisfaction, and the positive effects of concreteness, reliability, sensitivity, and assurance dimensions on satisfaction were observed. The study showed that even in a relatively low competitive environment, customer satisfaction is still an important precursor to loyalty.

In the study made by Rather and Camilleri (2019, pp. 547-559), data were collected from luxury accommodation facilities in six cities of India. 410 out of 2450 targeted people who participated in the study. The study has proven that the combined effects of value fit and service quality can have an impact on consumer-brand identification and loyalty. The findings also proved to have an impact on consumer-brand identification and loyalty. The findings also showed that consumer brand identity, perceived service quality, and value fit are important pioneers of consumer-brand loyalty. Also, service quality and value fit, in terms of service quality and value fit, have moderate direct effects on consumer brand identity.

Rather and Hollebeek (2019, pp. 206-213) was performed with 25 randomly selected participants from seven of the hotel brands in India. As a result, customer satisfaction had a significant and medium-sized positive effect on emotional commitment. The strength of the relationship between trust and loyalty was highlighted by the necessity of providing services reliably and respectably. Trust is the driving force of emotional engagement in developing deeper and more important relationships with customers.

\section{The theoretical and managerial implications}

This study offers some contributions to CRM literature and provides managerial insights related to using digital technologies for organizational effectiveness. The theoretically grounded conceptualization of digital CRM capability positively influences customer relationship performance. Digital technologies facilitate capabilities that allow organizations to better meet the needs of customers. Another important contribution of this study is the examination of the dimensions of service quality and technological improvements on customer satisfaction by the structural equation model (SEM). As a result of the analysis, goodness of fit indices, $t$ values, standardized solution values have been examined. According to the results, the 
effect of service quality dimensions such as trust, sensitivity, and Enthusiasm on customer satisfaction is positive. Digital companies should give their customers trust. They should revise their product and service designs according to customers' preferences. It should be kept in mind that new product and service designs will increase customer demand. The relationship between independent variables and customer satisfaction (except reliability and concrete features) is significant. A strategic vision is useful for a digital transformation, but it should be based on customer needs and technological possibilities. Improving the quality of digital service as an organizational strategy requires senior management to support new technologies. Managers aim to go beyond unique technologies to develop a comprehensive digital technology capability with a well-defined digital transformation strategy. Successful digitization provides long-term, positive, and clear benefits to the organization. Creating an engaging customer experience is the cornerstone of digital transformation. The organization should internalize customer experiences and increase customer engagement through new digital channels. Data should be collected to analyze customer experiences. Innovation trends should be sustained and the company's digital and physical customer experience should be run smoothly. Every digital development based on customer experience will bring new opportunities to the organization. To respond to a large number of customer requests, virtual customer support centers will become widespread throughout the organizational structure and will consist of more staff hierarchies. CRM systems will be designed more technologically in the future to ensure the formal flow of information.

Research results are compatible with the results Landrum and Prybutok (2004, pp. 631634) and Caruana et al. (2000, p. 1348). Also, Rather and Hollebeek (2019, p. 1436) and Rather (2020, pp. 22-26) also observed that among relationships customer satisfaction with loyalty, trust, and behavioral intentions. Also, our research results indicate that the capacity of a digital company to create demand for its products and the trust it creates in its customers has an impact on customer satisfaction. This result is compatible with the findings of Rather (2018a, pp. 498-506) indicating that customer satisfaction has been directly identified as a precondition for the development of trust and customer loyalty. Rather and Hollebeek (2019, pp. 206-213) found that trust affected the emotional engagement and satisfaction of the customers. To conclude, a significant relationship has been found between different dimensions of service quality and the most effective independent variable on customer satisfaction is trust and enthusiasm. This result shows that customer experience is effective in the performance of digital CRM. In addition to other scientific studies in the literature, enthusiasm has also been observed to affect customer satisfaction. If customers know that their personal information and data are protected during digital CRM applications, their loyalty to digital marketing tools and brand identification will increase. Businesses implementing digital CRM should direct the demands of their customers in a way that makes their products and services attractive. Various other factors including customer engagement (Hollebeek et al., 2019; Islam et al., 2020), customer brand identification (Rather et al., 2018), customer experience (Rather \& Hollebeek, 2020), customer attitudes (Rather, 2018b), brand credibility (Rather \& Hollebeek, 2020; Shams et al., 2020), value co/creation (Rather et al., 2019b), service innovation (Hollebeek \& Rather, 2019) and customer loyalty (Raza et al., 2020) can be included in the proposed framework, which may impact the magnitude of anticipated relationships. In 
future research, whether customer expectations provide effective feedback to the management should be taken into consideration, and evaluation of service performance according to managerial purposes. Information managers must know how their organizations will meet customer needs. Although service quality is a single factor that contributes to success, it may not be enough to measure it alone (Landrum \& Prybutok, 2004, p. 639). Parasuraman et al. (1994) state that managers should be more concerned with identifying deficiencies in services than a valid measure of service quality.

\section{Conclusions}

This study offers some contributions to CRM literature and provides managerial insights related to using digital technologies for organizational effectiveness. The theoretically grounded conceptualization of digital CRM capability positively influences customer relationship performance. Digital technologies facilitate capabilities that allow organizations to better meet the needs of customers. Another important contribution of this study is the examination of the dimensions of service quality and technological improvements on customer satisfaction by structural equation model (SEM). As a result of the analysis, goodness of fit indices, $t$ values, standardized solution values have been examined. According to the results, the effect of service quality dimensions such as trust, sensitivity, and Enthusiasm on customer satisfaction is positive. Digital companies should give their customers trust. They should revise their product and service designs according to customers' preferences. It should be kept in mind that new product and service designs will increase customer demand. The relationship between independent variables and customer satisfaction (except reliability and concrete features) is significant. A strategic vision is useful for a digital transformation, but it should be based on customer needs and technological possibilities. Improving the quality of digital service as an organizational strategy requires senior management to support new technologies. Managers aim to go beyond unique technologies to develop a comprehensive digital technology capability with a well-defined digital transformation strategy. Successful digitization provides long-term, positive and clear benefits to the organization. Creating an engaging customer experience is the cornerstone of digital transformation. The organization should internalize customer experiences and increase customer engagement through new digital channels. Data should be collected to analyze customer experiences. Innovation trends should be sustained and the company's digital and physical customer experience should be run smoothly. Every digital development based on customer experience will bring new opportunities to the organization. To respond to a large number of customer requests, virtual customer support centers will become widespread throughout the organizational structure and will consist of more staff hierarchies. CRM systems will be designed more technologically in the future to ensure the formal flow of information.

Factors such as the fact that the study is made only in a specific province of the country, the language of the survey are Turkish, the level of education and knowledge of the respondents, and the facts that the study is only related to the digital service sector limit the study. In this context, more research can be conducted in different environments and comparisons between contexts can be made. The main innovation of the study is to explain customer 
satisfaction in the digital service sector, which is growing with the industry 5.0 revolutions, by considering the relationships between independent variables. Digital service companies should focus on the internal processes of the service rather than the external features. Trust and reliability factors for quality in digital services will come to life with the protection of personal data. To increase the specificity of the study, the relational hypotheses between independent variables were explained with two different models.

This study focuses solely on digital service satisfaction. Other academic studies can be done in any of the digital service sectors (hospitality, education, tourism, and business-tobusiness markets). Future researches can use our model based on our research design in different cultures and countries. Cross-sectional data were used in this study. Future research should be done with longitudinal data and other sampling techniques.

In future, it should also be emphasized that the means to be used during the provision of digital services and the quality of the personnel working in customer communication centers should be increased. It is clear that digital marketing will gain more importance in the future. Accordingly, researches on how businesses will direct the preferences of certain target audiences to create demand and make their products and services more attractive will have a wide impact in the scientific world.

\section{Author contributions}

Demokaan Demirel conceived the study and was responsible for the design and development of the data analysis.

\section{Disclosure statement}

I have no conflict of interest.

\section{References}

Banner, M. (2018). Digital presence and transformation: The growing importance of digital presence in today's business marketplace [Business Administration Programme Thesis]. Centria University of Applied Sciences, Finland. https://www.theseus.fi/handle/10024/150998

Berman, S. (2012). Digital transformation: Opportunities to create new business models. Strategy \& Leadership, 40(2), 16-24. https://doi.org/10.1108/10878571211209314

Caruana, A. (2002). Service loyalty: The effects of service quality and mediating role of customer satisfaction. European Journal of Marketing, 36(7/8), 811-828. https://doi.org/10.1108/03090560210430818

Caruana, A., Money, H. A., \& Berthon, R. P. (2000). Service quality and the satisfaction - the moderating role of value. European Journal of Marketing, 34(11/12), 1338-1352. https://doi.org/10.1108/03090560010764432

Demirkan, H., \& Spohrer, J. (2018). Service transformation enabled by digital: Smart machines. Journal of Service Management Research, 2, 8-11.

Fritzsche, A., \& Ng, I. C. L. (2018). The language of the revolution. Journal of Service Management Research, 2, 14-16. 
Heavin, C., \& Power, D. J. (2018). Challenges for digital transformation towards a conceptual decision support guide for managers. Journal of Decision Systems, 27(1), 38-45. https://doi.org/10.1080/12460125.2018.1468697

Hollebeek, L. D., \& Rather, R. A. (2019). Service innovativeness and tourism customer outcomes. International Journal of Contemporary Hospitality Management, 31(11), 4227-4246. https://doi.org/10.1108/IJCHM-03-2018-0256

Hollebeek, L. D., Sprott, D. E., Andreassen, T. W., Costley, C., Klaus, P., Kuppelwieser, V., Karahasanovic, A., Taguchi, T., Ul Islam, J., \& Rather, R. A. (2019). Customer engagement in evolving technological environments: Synopsis and guiding propositions. European Journal of Marketing, 53(9), 2018-2023. https://doi.org/10.1108/EJM-09-2019-970

Hooper, D., Coughlan, J., \& Mullen, M. (2008). Structural equation modelling: Guidelines for determining model fit. Electronic Journal of Business Research Methods, 6(1), 53-60.

https://arrow.tudublin.ie/buschmanart/2/

Hsu, T. T., Tsai, H. K., Hsieh, H. M., Wang, W. Y. (2014). Strategic orientation and new product performance: The roles of technological capability. Canadian Journal of Administrative Sciences, 31(1), 44-58. https://doi.org/10.1002/cjas.1274

Hu, H.-H., Kandampully, J., \& Juwaheer, T. D. (2009). Relationships and impacts of service quality, perceived value, customer satisfaction, and image: an empirical study. The Service Industries Journal, 29(2), 111-125. https://doi.org/10.1080/02642060802292932

Huang, L. P., Lee Y. C. B., \& Chen, C. C. (2019). The influence of service quality on customer satisfaction and loyalty in the B2B technology service industry. Total Quality Management \& Business Excellence, 30(13), 1449-1465. https://doi.org/10.1080/14783363.2017.1372184

Islam, J. U., Shahid, S., Rasool, A., Rahman, Z., Khan, I., \& Rather, A. R. (2020). Impact of Website attributes on customer engagement in the banking: A solicitation of stimulus-organism-response theory. International Journal of Bank Marketing, 38(6), 1279-1303.

https://doi.org/10.1108/IJBM-12-2019-0460

Kaplan, A. M., \& Haenlein, M. (2010). Users of the World, Unite! The challenges and opportunities of Social Media. Business Horizons, 53(1), 59-68. https://doi.org/10.1016/j.bushor.2009.09.003

Karadeniz, M., \& Gözüyukarı, M. (2015). TSosyal CRM Uygulayan Şirketler Tarafından Sunulan Hizmet Kalitesinin Müşteri Memnuniyeti Üzerine Etkisi [The effect of service quality provided by social CRM companies on customer satisfaction]. Marmara Üniversitesi Öneri Dergisi, 11(44), 236-256.

Kumar, V., \& Reinartz, W. (2018). Customer relationship management. Springer Texts in Business and Economics. Springer-Verlag. https://doi.org/10.1007/978-3-662-55381-7

Kuo, Y.-F., Wu, C.-M., \& Deng, W.-J. (2009). The relationships among service quality, perceived value, customer satisfaction, and post-purchase intention in mobile value-added services. Computers in Human Behaviour, 25(4), 887-896. https://doi.org/10.1016/j.chb.2009.03.003

Landrum, H., \& Prybutok, R. V. (2004). A service quality and success model for the information service industry. European Journal of Operational Research, 156(3), 628-642. https://doi.org/10.1016/S0377-2217(03)00125-5

Laudon, J. P., \& Laudon, K. C. (2017). Management information systems: Managing the digital firm. Pearson Publishing. https://www.pearson.com/uk/educators/higher-education-educators/product/ Laudon-Management-Information-Systems-Managing-the-Digital-Firm-Global-Edition-15th-Edition/9781292211756.html

Lee, I. (2017). Big Data: Dimensions, evolution, impacts, and challenges. Business Horizons, 60(3), 293-303. https://doi.org/10.1016/j.bushor.2017.01.004

Loonam, J., Eaves, S., Kumar, V., \& Parry, G. (2018). Towards digital transformation: Lessons learned from traditional organizations. Strategic Change, 27(2), 101-109. https://doi.org/10.1002/jsc.2185 
Matt, C., Hess, T., \& Benlian, A. (2015). Digital transformation strategies. Business \& Information Systems Engineering, 57(5), 339-343. https://doi.org/10.1007/s12599-015-0401-5

Matzner, M., \& Büttgen, M.(2018). Viewpoints on the transformation process. Journal of Service Management Research, 2, 4-8.

Muther, A. (2002). Customer relationship management. Electronic Customer Care in the New Economy. Spring-Verlag. https://doi.org/10.1007/978-3-642-56222-8

Ortiz, P. M., Devece, C., \& Hikkerova, L. (2019). How mobile technologies support business models: Case study-based empirical analysis. Canadian Journal of Administrative Sciences, 37(1), 95-105. https://doi.org/10.1002/cjas.1550

Pansari, A., \& Kumar, V. (2017). Customer engagament: The construct, antecedents and conseguences. Journal of the Academy of Marketing Science, 45, 294-311. https://doi.org/10.1007/s11747-016-0485-6

Parasuraman, A., Zeithaml, V. A., \& Berry, L. L. (1988). SERVQUAL: A multiple-item scale for measuring consumer perceptions of service quality. Journal of Retailing, 64(1), 12-40.

https://www.researchgate.net/publication/225083802_SERVQUAL_A_multiple-_Item_Scale_for_ measuring_consumer_perceptions_of_service_quality

Parasuraman, A., Zeithaml, V. A., \& Berry, L. L. (1994). Reassessment expectations as a comparison standard in measuring service quality: Implications for further research. Journal of Marketing, 58(1), 111-124. https://doi.org/10.1177/002224299405800109

Perkin, N., \& Abraham, P. (2017). Building the agile business through digital transformation ( $1^{\text {st }}$ ed.). Kogan Page Ltd. https://www.amazon.com/Building-Business-through-Digital-Transformation/dp/0749480394

Podsakoff, P. M., Mackenzie, S. B., Lee, J.-Y., \& Podsakoff, N. P. (2003). Common method biases in behavioral research: A critical review of the literature and recommended remedies. Journal of Applied Psychology, 88(5), 879-903. https://doi.org/10.1037/0021-9010.88.5.879

Rajola, F. (2003). Customer relationship management. Organizational and technological perspectives. Springer-Verlag. https://doi.org/10.1007/978-3-540-24718-0

Rather, A. R. (2018b). Exploring customers' attitudes towards the hospitality brands in India: A social identity perspective. In M. A. Camilleri (Ed.), The branding of tourist destinations: Theoretical and empirical insights (pp. 207-231). Emerald Publishing Limited. https://doi.org/10.1108/978-1-78769-373-920181012

Rather, R. A. (2018a). Investigating the impact of customer brand identification on hospitality brand loyalty: A social identity perspective. Journal of Hospitality Marketing Management, 27(5), 487-513. https://doi.org/10.1080/19368623.2018.1404539

Rather, R. A. (2020). Customer experience and engagement in tourism destinations: The experiential marketing perspective. Journal of Travel Tourism Marketing, 37(1), 15-32.

https://doi.org/10.1080/10548408.2019.1686101

Rather, R. A., \& Hollebeek, D. L. (2019). Exploring and validating social identification and social exchange-based drivers of hospital customer loyalty. International Journal of Contemporary Hospitality Management, 31(3), 1432-1451. https://doi.org/10.1108/IJCHM-10-2017-0627

Rather, R. A., Tehseen, S., Itoo, H. M., \& Parrey, H. S. (2019a). Customer brand identification, affective commitment. customer satisfaction and brand trust as antecedents of customer behavioral intention of loyalty: An empirical study in the hospitality sector. Journal of Global Scholars of Marketing Science, 29(2), 196-217. https://doi.org/10.1080/21639159.2019.1577694

Rather, R. A., \& Camilleri, M. A. (2019). The effects of service quality and customer-brand value congruity on hospitality brand loyalty. Anatolia: An International Journal of Tourism and Hospitality Research, 30(4), 547-559. https://doi.org/10.1080/13032917.2019.1650289 
Rather, R. A., \& Hollebeek, L. D. (2020). Experiential marketing for tourism destinations. In S. K. Dixit, The Routledge handbook of tourism experience management and marketing ( $1^{\text {st }} \mathrm{ed}$.). Routledge Publications. https://doi.org/10.4324/9780429203916-24

Rather, R. A., Hollebeek, L., D., \& Islam, J. U. (2019b). Tourism-based customer engagement: The construct, antecedents, and consequences. The Service Industries Journal, 39(7-8), 519-540. https://doi.org/10.1080/02642069.2019.1570154

Rather, R. A., Najar, A. H., \& Jaziri, D. (2020). Destination branding in tourism: Insights from social identification, attachment, and experience theories. Anatolia, 31(2), 229-243. https://doi.org/10.1080/13032917.2020.1747223

Rather, R. A., Tehseen, S., \& Parrey, S. H. (2018). Promoting customer brand engagement and brand loyalty through customer brand identification and value congruity. Spanish Journal of Marketing, 22(3), 319-337. https://doi.org/10.1108/SJME-06-2018-0030

Raza, A., Rather, R. A., Iqbal, K. M., \& Bhutta, U. S. (2020). An assessment of corporate social responsibility on customer company identification and loyalty in banking industry: A PLS-SEM analysis. Management Research Review, 43(11), 1337-1370. https://doi.org/10.1108/MRR-08-2019-0341

Roach, D., Jonesi R., Ryman, J., \& Ryman, H. (2018). Enhancing innovatiness: The role of dynamic marketing capabilities. Canadian Journal of Administrative Sciences, 35(4), 563-576. https://doi.org/10.1002/cjas.1473

Robinson, S. (1999). Measuring service quality: Current thinking and future requirements. Marketing Intelligence Planning, 17(1), 21-32. https://doi.org/10.1108/02634509910253777

Saarikko, T., Ulrik, H. Westergren, \& Blomquist, T. (2017). The internet of things: Are you ready for what's coming. Business Horizons, 60(5), 667-676. https://doi.org/10.1016/j.bushor.2017.05.010

Sahut, M. J., Dana, L. P., \& Laroche, M. (2019). Digital innovations, impacts on marketing, value chain and business models: An introduction. Canadian Journal of Administrative Sciences, 37(1), 61-67. https://doi.org/10.1002/cjas.1558

Schermelleh-Engel, K., Moosbrugger, H., \& Müller, H. (2003). Evaluating the fit of structural equation models: Tests of significance and descriptive goodness-of-fit measures. Methods of Psychological Research Online, 8(2), 23-74.

Seijts, H. G., \& Gandz, J.(2018). Transformational change and leader character. Business Horizons, 61(2), 239-249. https://doi.org/10.1016/j.bushor.2017.11.005

Seth, N., Deskmukh, G. S., \& Vrat, P. (2005). Service quality models: A review. International Journal of Quality Reliability Management, 22(9), 913-949. https://doi.org/10.1108/02656710510625211

Shams, G., Rehman, M. A., Samad, S., \& Rather, R. (2020). The impact of the magnitude of service failure and complaint handling on satisfaction and brand credibility in the banking industry. Journal of Financial Services Marketing, 25, 25-34. https://doi.org/10.1057/s41264-020-00070-0

Tam, M. L. J. (2004). Customer satisfaction, service quality, and perceived value: An integrative model. Journal of Marketing Management, 20(7-8), 897-917. https://doi.org/10.1362/0267257041838719

Trainor, K. J., Andzulis, J. M., Rapp, A., \& Agnihotri, R. (2014). Social media technology usage and customer relationship performance: Capabilities based examination of social CRM. Journal of Business Research, 67(6), 1201-1208. https://doi.org/10.1016/j.jbusres.2013.05.002 


\section{APPENDIX}

\section{Scales and Items}

\section{A.1. Reliability}

Indicate the extent to which you have recently communicated with companies within the reliability relationships on a scale from 1 to 5, equals, where 1 equals totally agree and 5 never disagree

\section{Dimension 1: Organizational Reliability in digital service practices}

R1. When you have a problem implementing digital CRM companies your concerns tries to resolve.

R2. Implementing Digital CRM promises in companies on time.

R.3. Implementing Digital CRM companies are reliable.

R.4. Implementing Social CRM companies services fulfills on time.

\section{A.2. Concrete Features}

Evaluate the concrete features you touch in with companies on a scale from 1 to 5 , where 1 equals totally agree and 5 never disagree

\section{Dimension 2. Concrete Features in digital firms}

CF.1. Implementing Digital CRM company's digital media channels looks tidy and nice.

CF.2. Digital media tools used by companies implementing digital CRM are beautiful.

CF.3. The social media accounts of companies implementing digital CRM are directly compatible with the type of service offered.

C.F.4. Companies implementing digital CRM have modern equipment.

\section{Dimension 3. Enthusiasm against services in digital firms}

Evaluate enthusiasm to served digital services by digital companies on a scale from 1 to 5 , where 1 equals totally agree and 5 never disagree.

E.1. The services of companies that implement digital CRM to customers are fast.

E2. Companies implementing digital CRM tell them when the service will be offered to customers.

E.3. Staffs of companies implementing digital CRM are friendly and willing to serve their customers at any time.

E.4. Staffs of companies implementing digital CRM are never too busy to meet customers' demands.

\section{Dimension 4. Trust}

Evaluate how reliable are the digital companies you communicate with on a scale from 1 to 5 , where 1 equals totally agree and 5 never disagree 
T.1. Customers feel safe in transactions with companies that implement digital CRM.

T.2. The attitudes and behavior of the employees of the company implementing digital CRM creates a sense of trust in the customers.

T.3. Company staffs who apply digital CRM are understanding and polite.

T.4. Company staffs who apply digital CRM have the knowledge and skills to solve customers' problems.

\section{Dimension 5. Sensitivity}

Evaluate your sensitivity communicated with digital firms on a scale from 1 to 5, where 1 equals totally agree and 5 never disagree.

S.1. Company staffs who implement digital CRM understand the specific needs of their customers.

S.2. In companies that apply Digital CRM, you will be personally shown interest and relevance.

S.3. In companies that implement digital CRM, the interests of customers are taken care of sincerely.

S.4. Companies that implement digital CRM have reasonable working hours for all customers.

\section{Dimension 6. Customer Satisfaction}

When responding to the following items, consider your satisfaction situation for the digital services. Evaluate each item on a scale from 1 to 5, where 1 equals totally agree and 5 never disagree.

CS.1. Companies that implement digital CRM services always meet my expectations.

C.S.2. I am satisfied with the service quality of companies implementing digital CRM.

C.S.3. I recommend the companies that apply digital CRM to my friends.

C.S.4. I plan to use companies that implement Digital CRM services in the future. 